\title{
McCune-Albright syndrome
}

INSERM

\section{Source}

INSERM. (1999). Orphanet: an online rare disease and orphan drug data base. McCuneAlbright syndrome. ORPHA:562

McCune-Albright syndrome (MAS) is classically defined by the clinical triad of fibrous dysplasia of bone (FD), café-au-lait skin spots, and precocious puberty (PP). 